\title{
How to value a patent: a simple formula for lost profits patent damages
}

\author{
Young S. Yoo' \\ Economist, Federal Energy Regulatory Commission (FERC), USA
}

Stephen P. Magee

Bayless Chair and Prof. of Finance and Economics

Department of Finance, University of Texas, USA

\section{Keywords}

Economic models, intellectual property, lost profits, patent damages, patent lost profits, patent valuation

\begin{abstract}
Patents are valuable only when they are enforced in court. The purpose of this paper is to measure a patent owner's profits that are lost when a competing firm unlawfully makes infringing sales. Our microeconomic methodology computes a two-firm duopoly equilibrium with an infringer present and compares it with the same market but with the infringer removed. The second equilibrium represents a legally sanctioned single-firm patent monopoly. We derive a single equation representing the lost profits damage percent to be paid to the patent owner by the infringer. We incorporate product demand, both firms' marginal costs, output, market shares, and prices in our equation. There are three contributions of this paper.

One, we derive the simplest duopoly/monopoly damage equation we have seen that captures all the economic effects into a single percentage damage number.

Second, that damage percent multiplied times the patent owner's actual profits (with infringement ongoing) equals the dollar damages the infringer should pay in court for the patent owner's lost profits.

Third, we apply our formula to a small pilot study of classic US patent lost profit cases and find that our equation's damage predictions had a correlation of .71 with the actual Federal court damage outcomes.

We also illustrate the use of the formula. For example, if a patent owner's actual profits on its patented product was $\$ 10$ million with infringing sales present, then lost profits damages due to the patent owner would be $\$ 12.5$ million if the two firms' sales were equal. Patent damages increase to over $\$ 40$ million if the infringer's market share increased to triple that of the patent owner in the two-firm market.
\end{abstract}

Corresponding author: Stephen P. Magee

Email address for corresponding author: magee@mail.utexas.edu

First submission received: $3^{\text {rd }}$ January 2019

Revised submission received: $19^{\text {th }}$ March 2019

Accepted: 21st March 2019

\section{Introduction}

We derive the simplest formula we have seen for valuing patent lost profits damages. The formula is important because patented inventions are a foundation of US economic success in an information world. The global economic importance of patents has been shown in several papers in the Journal of Development Economics. Gould and Gruben (1996) showed that strong intellectual property rights led to

1 The views expressed in this paper are those of the authors and do not reflect the views of the FERC or any individual Commission at FERC.

www.ijbed.org A Journal of the Academy of Business and Retail Management (ABRM) 
significantly higher country growth rates. Schneider (2005) found that innovation is significantly higher in developed countries with high patent protection indexes.

Patented ideas are called "contrived goods" because they have value only when protected in court. But even in the US, patents are widely infringed and undercompensated. One study showed that of 36,000 US cases filed since 2000 , less than 4,000 of them (11\%) resulted in damage payments to the patent owner. This is surprising given that intangible capital, including patents, constitutes almost $80 \%$ of the per capita wealth in the US and in OECD countries. Natural resources and produced capital constitute the rest. ${ }^{2}$ Global infringement of US patents is widespread, witness the current battle between the US and China over American intellectual property. One reason given for the difficulty of enforcing patents in the US is explaining complex damages to judges and juries. We reduce this complexity with our simple valuation formula. The economic formula developed here should work in most countries.

Using mathematical microeconomics, we solve a complex of equations that yield a remarkable formula that estimates the patent lost profit patent damage percentage requiring only the market share of the patent owner in the combined sales by the two firms. Here is the lost profits damage formula (derived in equation (10) near the end of the paper) where $s$ is the patent owner's actual market share in the combined sales of the new product by the two firms.

$$
\text { Damage Percentage } X=\frac{(1+s)^{2}}{4 s^{2}}-1.0
$$

The variable $X$ is the percentage of (multiple times) the patent owner's actual dollar profits (with infringement ongoing) which the infringer should pay in lost profits patent damages. This formula applies only to product enhancement (not costs saving) inventions that differentiate the product from the rest of the market. Thus, the relevant market is a two-firm duopoly. We will discuss this assumption at greater length later.

The equation is remarkable because it provides simple approximations of lost profit damages without explicit measurement of either the demand curve or the marginal costs of the two firms. Data combined with and our equations reveal these variables in our merging of the infringing/non-infringing (duopoly/monopoly) formulas. We have not seen a formula like this that estimates lost profit patent damages using only the sales of the patent owner, the infringer and patent owner's actual profits with infringement ongoing. The demand slope cancels out because it appears in both the numerator and denominator of our equation and observed market shares fully reveal the relative marginal costs of the two firms. This is what allows our lost profits damage percent, $X$, in the equation above to be explained by the single market share variable, s.

Until now, court calculations of lost profits damages were complex and arcane, requiring difficultestimation of demand, price, cost and profit variables. After three decades of teaching managerial microeconomics and testifying in over 100 patent infringement cases, we happened upon this shortcut formula. A small pilot study in Figure 1 below applies the model to several classic historical cases. That percentage times patent owner actual profits equals the dollar value of patent damages and allows precase filing damage approximations with limited case-specific information. Figure 1 is not a statistical test but is only indicative because of the small number of observations.

2 Ronald Bailey, “The Secrets of Intangible Wealth," Wall Street Journal Online, p 49, 9-29-2007. http:/ / online.wsj.com/article_print/SB119103046614343129.html 


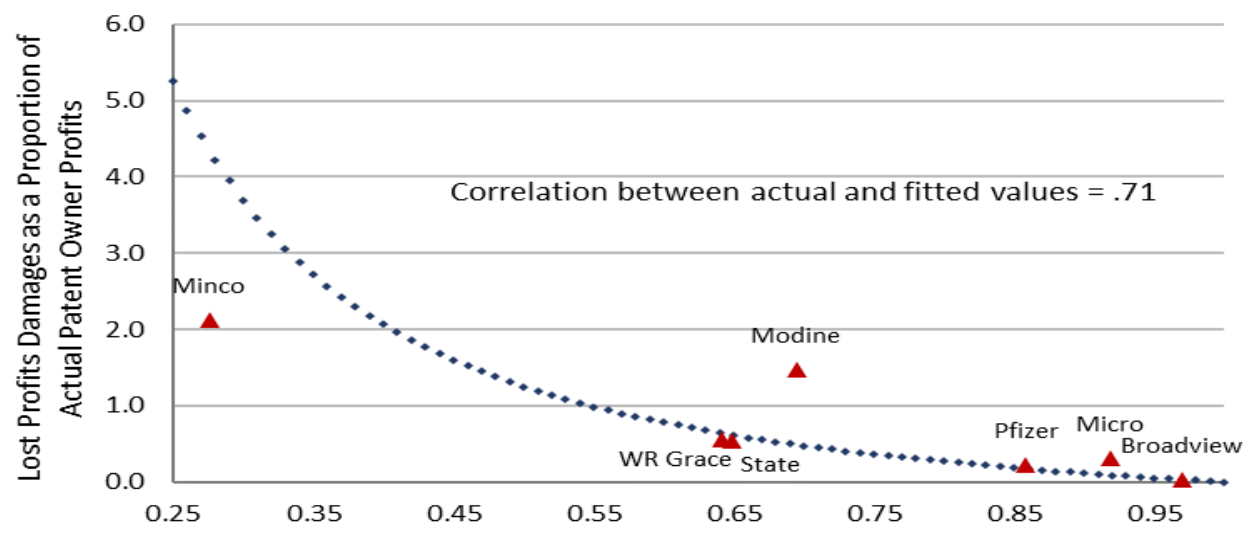

Patent Owner Firm Market Share of Sales of the Two-Firms

Damage Percentage $=\frac{(1+s)^{2}}{4 \pi^{2}}-1.0$

Figure 1: Actual \& Our Predicted (Dotted Line) Court Damages as Percent of Patent Owner Profits.

We noted above our assumption that the patented invention sufficiently differentiates the products sold by the patent owner and the infringer from all other products in the market. Since these products are distinct from products in the market without the technology, the submarket can be described in antitrust terms as a simple two-firm duopoly. If the technology in the infringer's products is "reasonably interchangeable" with the patent owner's, then there is infringement. The fact of interchangeability is determined in the liability portion of patent trials. If the court finds that the defendant's technology is not reasonably interchangeable with the patent owner's, then there is no infringement and hence no damages.

We are using market shares in the two firm market to calculate patent damages. Thus, the effects of firm advertising on sales must be removed by experts from the firm market shares used in the damage equation. If the patented innovation does not sufficiently differentiate it from non-infringing product alternatives, then that analysis must also be accounted for by testifying economic and technical experts before applying our formula. As noted, our formula only applies to product enhancement inventions, not cost-saving inventions.

Damage predictions based on our equation are illustrated below in Table 1. The last column illustrates our \% of patent infringement lost profits damages due to the patent owner. The predictions in Table 1 come from equation (10), derived below. The equation is shown on this page above. The dollar value of lost profits damages due to the patent owner equal the percentage (proportion) in the last column multiplied times the patent owner's actual dollar profits during the period of infringement. Note that if the patent owner market share equals the infringer's in sales by the two firms, then lost patent damages due to the patent owner equal 1.25 times its actual patent owner profits with infringement ongoing. If the infringer has 3 times the share of the patent owner, (75-25 in row 1 of the table) then lost patent damages due to the patent owner are 5.25 times the patent owner's actual profits, or more than 4 times higher than the 1.25 multiple. Lost profits damages are what the patent owner's profits would have been in the absence of infringement. Ironically, we find later in the paper that it is mathematically easier to determine the economic value of a patented invention to the innovating firm when an infringer is present. 


\begin{tabular}{ccc}
\hline $\begin{array}{c}\text { Patent Owner Share } \\
s\end{array}$ & $\begin{array}{c}\text { Infringer Share } \\
(1-s)\end{array}$ & $\begin{array}{l}\text { Multiply This Times } \\
\text { Patent Owner Actual Profits } \\
\text { to Get Damages }\end{array}$ \\
\hline 0.25 & 0.75 & 5.25 \\
0.30 & 0.70 & 3.69 \\
0.40 & 0.60 & 2.06 \\
0.50 & 0.50 & 1.25 \\
0.55 & 0.45 & 1.00 \\
0.60 & 0.40 & 0.78 \\
0.70 & 0.30 & 0.47 \\
0.80 & 0.20 & 0.27 \\
0.90 & 0.10 & 0.11 \\
\hline
\end{tabular}

Table 1: The Formula's Damage Percentage to Multiply Times Patent Owner Actual Profits (Shares are of the Combined Actual Sales of the Patent Owner and the Infringer)

An intuitive explanation why our patent lost profits damage formula is so simple

Our lost profits damage formula is based on the following assumptions and observations.

The patent damage formula applies to a product enhancement that makes a product more desirable to buyers. It does not apply to cost-saving inventions.

The formula works best when the patent owner and infringer are selling similar products, but the patented invention differentiates these products from others in the market. In this case, there is a single aggregate demand curve for the two products and both firms are assumed rational and maximize their profits.

The slope of the aggregate product demand curve is the same with only one seller present (the patent owner only) or two sellers present (with the infringer also selling).

One mathematical discovery with our patent damage formula is that the slope of the demand curve did not appear in the final equation. Why not? Where did it go?

It is incorporated into the solution but disappeared because the slope of the aggregate demand curve is the same irrespective of whether one or two sellers are present.

Another reason is that the numerator in the formula has the patent owner profit \% if only one seller is present while the denominator has the patent owner profit \% if both sellers are present. Since the intercept and the demand slope appears in both the numerator and the denominator, they cancel out and have been accounted for but are not required in the final formula.

Thus, while aggregate demand for sales by the two sellers is fully incorporated into our patent damage formula, it does not appear in the final solution and thus is not explicitly required to calculate the lost profits damage percentage in actual patent infringement court cases.

Marginal costs also do not appear explicitly in the final formula because with linear marginal costs and linear demand, each firm's market shares in a two-firm market fully reflect marginal costs. It turns out that market shares are inversely proportional to each firm's marginal costs - the firm with the larger market share has lower marginal costs.

Empirically of course, there can be slippage in the ability of firm market shares to exactly replicate marginal costs. In such cases, both firm's actual marginal costs and lost profits can be calculated exactly.

In such a case of using actual marginal costs in the formula instead of firm market shares, the demand curve slope still cancels out in the final damage equation.

An outline of the paper 
Section 2 of the paper below describes the legal system erosion of the patent protection in the United States. Section 3 is a review of the literature. Section 4 explains the mathematics and the derivation of our simple lost profits formula in equation (10) and other results. Section 5 describes the US patent cases from which the data in Figure 1 is taken. Section 6 contains conclusions, limitations and direction for future research. Section 7 is references; Section 8 contains acknowledgments and Section 9 is a mathematical appendix.

\section{The collapse of US patent protection}

A patent has value because it gives the patent holder temporary exclusive rights to their invention. Those rights confer monopoly profits to the inventor, thereby stimulating more innovation. Infringers free-ride and take away some of the inventor's monopoly profits. That is why infringement is illegal and patent owners are encouraged to sue infringers. Such suits also dissuade other potential infringers. But to the public and juries, monopoly power is viewed as evil, making enforcement of patent monopoly rights before juries difficult. Here are seven reasons why patent enforcement is collapsing.

First, US patent protection is declining because patents are so are hard to value. Janicke and Ren (2006), found that only $25 \%$ of patent appellate cases in 2002-2004 in US courts resulted in a victory by the patent owner over the infringer. A study of all patent cases filed in 2008-2009 by Allison et al (2014) found that patent owners won only $26 \%$ of the time. More than 40,000 patent infringements cases have been filed from 2007 to 2017 and three quarters of them failed (Pridham (2017), Lex Machina (2018)). ${ }^{3}$ Lex Machina's 2013 annual report says that of the 36,629 cases filed since 2000, only 3.8 percent of cases resulted in any damages and only 1.9 percent reached a merits decision with compensatory damages, (Lex Machina, 2014) ${ }^{4}$

Second, juries, judges and attorneys all complain that patent cases are mind-bogglingly complex. A Federal judge once joked to us that he would prefer going to the dentist over presiding at a patent trial. A major difficulty in the US in proving lost profits damage cases is collecting the large amounts of data required for demand and costs for both the patent owner and the infringer. This paper requires only three observable variables which greatly simplifies lost profits infringement calculations and should improve the value of patents in court.

Third, patented ideas are public goods and are plagued by what economists call the "tragedy of the commons" Common goods like streets, highways and ideas are overused because they are either free or they appear to be free in infringer's eyes. The previous paragraph quantified the declining economic protection of patents. Large US corporate defendants in patent cases spend enormous sums relative to inventors and patent owners. This weakens US patent laws both in the courts and before the US Patent and Trademark Office (the USPTO). ${ }^{5}$ In today's global economy, international patent infringement is even more widespread because of the cost of extraterritorial enforcement. The core of America legal IP protection is eroding and with it, US high-tech leadership.

\footnotetext{
${ }^{3}$ See https:/ / www.forbes.com/sites/davidpridham/2017/04/13/the-patent-litigation-lie/\#39741cae7ea9.

4 See https://lexmachina.com/wp-content/uploads/2014/12/Damages-Reference-Sheet.pdf.

5 Lloyd (1980) explains the tragedy of the commons in history. In the Middle Ages, villagers would traditionally agree to regulate among themselves the maximum number of cows in the common. But when European mobility increased around the time of the Protestant Reformation, self-interest by newcomers to town led to an excessive number of cows and overgrazing. As a result, the commons collapsed as an economic and social institution leading to the term "tragedy of the commons." The same thing is happening with patents as private greed to avoid paying for patents leads to declines in the US American court system's protection of patents.
}

www.ijbed.org A Journal of the Academy of Business and Retail Management (ABRM) 
Fourth, the 'patent troll' attack on non-practicing owners of patents comes from heavy users of patents in the US. Pridham (2017) reports in Forbes that the US corporate attack on patents is "a wellfinanced propaganda campaign by large Silicon Valley-based technology companies to promote the view that America in recent decades has been suffering from an "explosion" of patent litigation unlike any in history...". ${ }^{6}$ Figure 2 below shows a chart cited by Pridham showing there has not been a patent litigation explosion: patent infringement cases filed since 1991 have increased no faster than the number of patents issued. ${ }^{7}$

Fifth, since public education is free, both juries and businesses view patented ideas like public roads and highways - why should I have to pay for ideas? Hence there is resistance to forcing infringers to pay for their use of patents. Patented commercial ideas are called "contrived goods" by economists because they have value only if legally protected, which requires legal enforcement.

Sixth, monopolies have a bad reputation in the mind of the public and juries, making patent enforcement difficult. The public fails to understand that patent monopolies encourage innovation by giving patent holders exclusive rights to their invention which gives monopoly profits to the inventor. The law also encourages patent owners to sue infringers to reduce free riding on inventor's rights and profits.

Seventh, the difficulty of catching patent infringers and collecting damages was well summed up by decision in the classic 1978 Panduit case:

"Except for the limited risk that the patent owner, over years of litigation, might meet the heavy burden of proving the four elements required for recovery of lost profits, the infringer would have nothing to lose, and everything to gain if he could count on paying only the normal, routine royalty that non-infringers might have paid. As said by this court in another context, the infringer would be in a "heads-I-win, tails-you-lose" position." 8

Thus, the expected value of infringing is high, and the probability of prosecution is low so that US patent infringement has increased.

\subsection{While US patent protection is declining, patent importance is increasing}

Despite declining protection, patent importance is increasing because the $21^{\text {st }}$ century is still in the information era. The information revolution in the last half century is the third greatest economic revolution in history, following the agricultural revolution in 8,000 $\mathrm{BCE}$ and the industrial revolution in the 1700s. Agricultural products and manufactures goods in the first two revolutions were private goods

\footnotetext{
6 Pridham quotes former Chief Judge Paul Michel of the Federal Circuit, the highest court in the United States for patents, saying that the 124 plus smartphone patents filed by the major smartphone manufacturers against each other in 2019-2012 are less than one-quarter of the number of patent cases filed in the telephone wars of Alexander Graham Bell's time when American Bell and AT\&T alone litigated 587 patent cases. He shows that in the Golden Age of the US Industrial Revolution the number of patent cases filed was 3.6 percent of the number of patents filed in that decade. He quotes Lex Machina's 2017 figures showing that in the decade since 2007, the number of patent cases filed was about half of that -1.9 percent.

7 The chart shows that patent issuance and infringement cases surged together in 1997-2001 and again in 2009-2014. But in general, the number of infringement cases filed has increased no faster the number of patents issued. This, there has been no "patent litigation explosion." Pridham also shows that the number of patents issued per billion dollars of GDP have remained roughly constant at 13 patents issued per billion dollars of GDP industrial output for the last half century. Many infringers call non-manufacturing patent owners (non-practicing entities) who attempt to enforce their patent rights against them "patent trolls." The infringer claim is that patent owners who were not the original inventors should not be allowed to monetize the value of the patents. But economics teaches that active secondary markets generally, and for patents, increase the efficiency of primary markets. The patent troll argument is like saying that home buyers should only be allowed to buy from the original builder and not from any intermediate owners.

8 Panduit Corp. v. Stahlin Bros. Fibre Works, Inc., 575 F.2d 1152, 1156 (6th Cir. 1978).
}

www.ijbed.org A Journal of the Academy of Business and Retail Management (ABRM) 
whose values are market determined. In contrast, the information revolution has created ideas which are public goods. Hence the evolution of the phrase describing patented ideas as "contrived goods" because their commercial value is dependent on government legal protection through patents and trade secrets. ${ }^{9}$

The United States made English the language of the internet and dominated the information revolution in the last a half century because of its large economy, sizable high-tech investments, the rule of law and strong intellectual property protection. Strong national legal systems generally explain why in 2017 over $20 \%$ of world income is earned in just three countries: the US, Germany and Japan. ${ }^{10}$

Fig 1: Patent case filings and grants

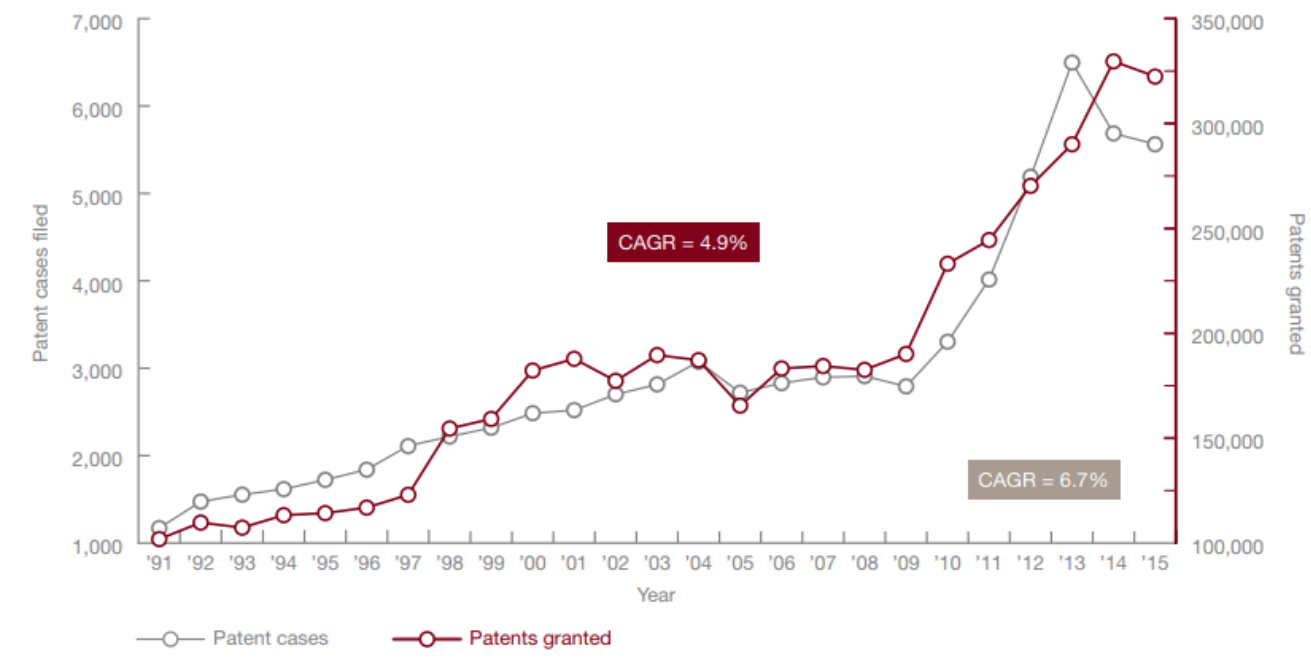

Years are based on September year-end.

Sources: Performance \& Accountability Report (USPTO) and Judicial Facts and Figures (US Courts)

Figure 2: The patent troll literature is wrong: patent litigation did not explode in the $21^{\text {st }}$ century: Patent court filings rose as fast as patents granted by the US Patent \& Trademark Office. Source: 2015 Patent Litigation Study, PwC

US legal strength has been a foundation of US economic power for over two centuries. But the current collapse of US patent protection is only one part of the fraying of the legal system. Political polarization of the political system is spilling over into law and damaging the US legal system. Witness the politicizing of the law in the battles over Federal judgeship appointments in the US Senate along party lines.

\subsection{The 1990s expansion and post-2000 stabilization in the share of lost profit damages}

A patent owner is entitled to recover economic damages if the defendant is found guilty of infringing a patent during the liability phase of a patent trial. Damages can be claimed as reasonable royalties, lost profits, or a combination or both. Traditionally, awards of reasonable royalties have been the most significant component of patent damages. But in the high-tech-dot-com boom of the 1990s, lost profits

${ }_{9}^{9}$ Nicholson and Snyder's (2008) monopoly chapter shows how barriers to entry differentiate some products.

${ }^{10}$ CIA data shows that $\$ 29$ out of $\$ 150$ trillion of world national income is earned in US, Germany and Japan. CIA

World Factbook https://www.cia.gov/library/publications/the-world-factbook/rankorder/2001rank.html.

www.ijbed.org A Journal of the Academy of Business and Retail Management (ABRM) 
damages became increasingly important. According to Davis and Kedrowski (1999) lost profits awards during the 1990 s increased from $16 \%$ to $29 \%$ of total patent damages.

In dollars, there was over a billion dollars in patent damage awards in the United States in 2017. Around 70 percent of that total or $\$ 763$ million were reasonable royalty damages. But lost profits damages are sizable at \$284 million or nearly 30 percent of total patent damages, a similar percent to the late 1990s, (Lex Machina, 2018). Thus, since the information revolution and dot-com explosion of the 1990s, lost profits damages have stabilized since 2000 at 30 percent of total patent infringement damages.

\subsection{Why it is so difficult to calculate patent damages in lost profit cases}

Historically, lost profits damage cases required econometric estimation of demand curves using the historical relationships between prices and units sold. But short histories for sales of new patented products render demand estimates unreliable. A parallel problem plagues econometric estimates of marginal cost curves. Thus, it is hard to know what the inventing firm should have earned in legally protected patent monopoly profits absent the infringer. On the surface, patent valuation would appear even more complex if an infringing firm was present and also selling the product.

Surprisingly, we discovered that it is easier to determine the true value of a patented invention to an innovating firm if an infringer is also present. There are several explanations for this puzzling result. First, with two firms selling the product containing the invention, there are more observations and hence more data available. Second, data analytics and microeconomic theory provide precise formulas for prices, costs and profits with two firms present (the patent owner and the infringer) compared to only one firm (the patent owner). A key assumption with academic support the two firms act in their own interest and thus maximize their profits. Using these insights, we derive a simple formula for the increase in profits of the inventing firm had the infringing firm not been present. That profit increase is called "patent infringement lost profits damages."

Using our model, econometric estimation of demand is not necessary. Even better, no direct measurement is required of the marginal costs of either the innovating firm or the infringing firm. It turns out that the ratio of marginal costs of the two firms are almost fully reflected in the sales of the inventing firm relative to the infringing firm. ${ }^{11}$

How can it be that neither the demand slope nor the marginal costs of the two firms explicitly appear in our equation? By accident, we saw that the slope of the demand curve appeared both in the numerator and denominator of our damage formula, so the slope canceled out. The demand equation is incorporated in the formula, but the element of the slope does not explicitly appear as a final term. An assumption of the model is that marginal costs are linear, but each firm can have different marginal costs. We know from our own merger studies that marginal costs get reflected in the market shares of the firms: the patent owner's market share $s$ is higher if the patent owning firm's marginal cost is lower.

An intermediate calculation in our formula yields the ratio of the inventor's monopoly profits with a single seller (i.e., monopoly profits of the patent owner in the absence of an infringer) to the patent owner's actual profits with the infringer present. This ratio minus 1.0 times the patent owner's actual profits equals the additional profits that the inventing firm should have made absent the infringement. Our equation incorporates the following three of four key variables required by the classic 1978 Panduit case in lost profits damage cases: demand for the patented product; what patent owner sales would have been in the absence of infringement; and what patent owner profits would have been in the absence of

11 This only requires that the marginal costs of the two firms be linear, which is approximately true in the neighbourhood of equilibrium and if the firms are not near full capacity. 
infringement; and adjustment for non-infringing alternatives. ${ }^{12}$ The fourth Panduit variable, not accounted for in our formula, is a lost profit damage estimate adjusted for non-infringing alternatives to the patented product. That adjustment can be made in the case by damage experts. Even without noninfringing alternative adjustments, the correlation was high between our predicted equation and the court awards reviewed below.

\section{A review of the literature}

Epstein (2003) examined lost profits damages which included price erosion damages building on State Industries v. Mor-Flo' in the late 1980s. That decision established the "market share" rule for lost sales based on that portion of the patent holder's relevant market that was captured by the infringer.

But in a two-firm world, the market share rule divides the infringing sales between the patent holder and the infringer. But an error in State Industries is that it ignores price erosion: prices in the "butfor" market (i.e., the market without infringement) would be higher than prices with infringement. These higher prices mean lower overall demand and hence a reduction in the calculated lost quantities sold. Epstein notes that the market share rule in State Industries does not account for the "price elasticity" effect because it ignores the price effect. Further, the US Federal Circuit stated in Crystal v. TriTech that the calculating price erosion damages independently of the lost sales damages is not credible due to price elasticity effects. ${ }^{13}$

Epstein's solution he labelled PERLS (Price ERosion and Lost Sales), which calculates patent lost profits damages as the difference between the patent holder's profits in the but-for market and profits in the actual market. Unfortunately, there are significant complexities in implementing PERLS and subsequent approaches to measuring both price erosion and lost sales in calculating lost profits damages. The following data is required at a minimum:

"PERLS requires a single additional parameter, the market price elasticity of demand, to insulate the analysis from the pitfalls identified by the Federal Circuit. Mathematically, PERLS is equal to the conventional implementation of the market share rule plus a single adjustment for price elasticity.

PERLS stands in a direct line of development of economic tools to analyze lost profit damages. The existing market share rule is equivalent to the special case of PERLS with no price erosion. Moreover, the insightful analysis offered by Judge Frank Easterbrook in Mahurkar is also a special case of PERLS with a price elasticity of demand equal to -1 and no non-infringing competitors. ${ }^{15}$ The PERLS damages calculation builds on these precedents in a tractable manner using data typically available in litigation.

By drawing on standard economic principles that have been used in numerous court proceedings, PERLS should yield damages that meet the standard of disciplined, "credible economic evidence" sought by the Federal Circuit."

Anton and Yao (2007) examine the impact of patent infringement damages in an equilibrium oligopoly model of process innovation where the choice to infringe is endogenous and affects market choices. Under the lost profits measure of damages normally employed by U.S. courts, they find that infringement always occurs in equilibrium with the infringing firm making market choices that alter the resulting market profit of the patent holder. That paper considered only a process innovation that lowers cost. In contrast, this paper considers a new product or differentiated product.

In addition, our formula incorporates both price erosion and lost unit sales effects. We can provide separate estimates of but-for product prices in the absence of infringement that would satisfy causation

12 Panduit Corp. v. Stahlin Bros. Fibre Works, Inc., 575 F.2d 1152, 1156 (6th Cir. 1978).

13 Crystal Semiconductor Corp. v. Tritech Microelectronics Int'l, Inc., 246 F.3d 1336, 1361(Fed. Cir. 2001).

www.ijbed.org A Journal of the Academy of Business and Retail Management (ABRM) 
requirements in the State Indus., Inc. v. Mor-Flo (1998) and Crystal Semiconductor (2001) cases. ${ }^{14}$ "Thus, a patentee may obtain lost profit damages for that portion of the infringer's sales for which the patentee can demonstrate 'but for' causation and reasonable royalties for any remaining infringing [sales];" the latter according to Bohrer et al. (2009).

Our approach on price erosion analysis is much simpler than the analysis of others, such as in Epstein (2003), which requires econometric estimate of the demand price elasticity. Epstein also allows more than two firms in the market and considers the market share of the owner patent as a share of the non-infringing market. This work addresses the lost profit due to price erosion as one of the two components of our estimated lost profit damages of the duopoly-monopoly markets in equilibrium next to the lost profits due to quantity reduction. While a number of studies focused on welfare consequences, or performance of patent damages regimes (Schankerman and Scotchmer, 2001, 2005; Anton and Yao, 2007; Choi 2009, and Henry and Turner 2010), our paper here focuses on simplifying lost-profits patent infringement damages.

As established by Panduit v Stahlin Bros (1978), to determine whether profits have been lost as a result of the patent infringement, the plaintiff must prove (1) demand for the patented product, (2) absence of acceptable non-infringing substitutes, (3) manufacturing and marketing capability to exploit the demand, and (4) the patent owner profits absent infringement. Our approach here simplifies difficult to quantify elements (1) and 4). For a paper with good damage intuition, see Keeley (1999).

In patent infringement cases, a patent owner's lost profits damages are not easy to calculate because they are the sum of two components; lost profits due to quantity reduction and lost profits due to price erosion. Lost profit due to quantity reduction represents the difference between the profits the patent owner would have earned without infringement, and its actual profits with infringement, under the assumption that the price remains the same in the but-for and actual situation. Lost profit due to price erosion represents the profits lost because of the infringer's price competition. In assessing lost profits, therefore, it is critical to construct a hypothetical market equilibrium conditions that may have prevailed "but-for" infringement so as to compare the difference between the patent owner's profits "had the infringer not infringed" with its actual profits with infringement. Unfortunately, lost profit calculations sometimes fail to measure price erosion because it is difficult to measure.

The proper economic measure of lost profits due to quantity reduction differs somewhat from the legal standard. The legal standard is that the maximum a patent owner could capture would be all of the infringer's sales, if it could demonstrate that it had the production capability and could outcompete rival firms for those sales. However, we know that this overstates the quantity effect because, absent the infringer, the higher price in the market would generate less total quantity sold than both firm's sales with infringement. Thus, absent infringement, the patent owner could not maintain its former sales and capture all of the infringer's sales too. An example of this legal error appears in Pfizer v. International Rectifier Corporation (1983) in which the court found that, absent infringement, patent owner Pfizer would have made all of the sales of the infringer.

Some researchers have tried to cope with all of these lost profits problems using a simulation approach (see, for example, Werden et al. (2000)). Unfortunately, the simulation cure is as complicated as the original problem and simulation still requires data for several hard to measure variables, such as industry demand and both firm's marginal costs.

14 State Indus., Inc. v. Mor-Flo Indus., Inc., 883 F.2d 1573, 1578 (Fed. Cir. 1989); and Crystal Semiconductor Corp. v. Tritech Microelectronics Int'l, Inc., 246 F.3d 1336, 1361(Fed. Cir. 2001). 


\subsection{Transition from the literature to our model}

Our approach is a simple one. Consider a duopoly market consisting of the patent owner and the infringing firm. We measure how much the patent owner's actual profits would increase from the actual situation of infringement (in the Cournot duopoly equilibrium) compared to the "but-for" situation of no infringement (the monopoly equilibrium). We show that the patent owner's profits without infringement will be higher than actual profits with infringement by a percentage multiple that is a function only of the patent owner's market share with infringement.

In the simplest case of two firms with identical marginal costs of production and identical market preferences for the firms' products (so that market shares are equal with infringement), we get the well-known 1.25 damage percentage or multiple to apply to the patent owner's actual profits. That is, patent infringement lost profits damages will equal 5/4 times the patent owner's actual profits with infringement. Other studies as that of Nieberding (2003) in the Crystal Semiconductor case estimated similar values (9/8). Our formula in this paper is parallel to the years of "rule of thumb" estimates used in computing reasonable royalties, (Gaff, 2015).

As stated in the Abstract, our summary damage equation above Table 1 predicts that if a patent owner's actual profits were $\$ 10$ million with infringement, then lost profits damages would equal $\$ 12.5$ million if the two firm's sales were equal. The damages increase to $\$ 40$ million if the infringer share was triple that of the patent owner. Recall that the formula applies only to product enhancement inventions, not cost saving inventions. In our model below, we consider first the case of duopoly market, in which the patent owner and an infringer are the only competitors. If the infringer went away, the patent owner would be a legal monopolist in this market. In the Introduction to the paper, we showed that the formula predicts outcomes in a small pilot study of seven actual U.S. patent infringement cases. But that is not a statistical test because of the small sample size.

\section{The mathematics underlying our simple patent lost profits equation}

Consider a Cournot duopoly consisting of only a patent owner (firm 1) and an infringer (firm 2) both selling the same products and both incorporating the invention. Since these two firms and these products are differentiated by the invention from the rest of the market, they are a separate twofirm product market. The patent owner has a legal right to the patented invention, but the infringer does not.

We assume that both firms face a linear industry demand curve and has constant marginal production costs, but marginal costs differ between the firms. As stablished in the literature, linear market demand combined with constant marginal costs guarantees the existence and the uniqueness of a Cournot equilibrium (See, for example, Tirole (1988)). Let the market inverse demand function and each firm's cost function be written as follows:

$$
\begin{aligned}
& p(X)=a-b X \\
& c_{i}=c\left(x_{i}\right)
\end{aligned}
$$

Where:

$$
\begin{aligned}
& p: \text { market-clearing price } \\
& x_{i}: \text { firm } i^{\prime} \text { s output }(i-1,2) \\
& c_{i}: \text { firm i marginal cost } \\
& X: \text { aggregate industry output }\left(X=x_{1}+x_{2}\right) \\
& \text { Therefore, each firm } i^{\prime} \text { s profits }\left(\pi_{i}\right) \text { are } \\
& \pi_{i}=(a-b X) x_{i}-c_{i} x_{i}
\end{aligned}
$$


Solving each firm's profit-maximization problem, it can be shown that

$x_{i}$ is the solution to $\max \left(\pi_{i}\right)$ where $\mathrm{i}=1,2$

Where:

\section{$p^{A}$ : actual market clearing price with 2 firms present (infringement)}

$\pi^{A}$ actual patent owner (firm $1^{\prime} s$ ) profits with inf ringement

Given this, the following equation, defines the patent owner firm 1's actual market share with infringement and both firms present:

$s \equiv \frac{x_{1}}{x_{1}+x_{2}}$

Where: $s=$ patent owner's actual market share with infringement

The term $a$ in (3) is the vertical intercept of the demand curve; $c$ equals the dollar value of the patent holding firm 1's marginal cost per unit. When neither firm has a cost advantage, then firm 2's $c_{2}$ equals firm 1's $c_{1}$ and thus firm 1's market share $s=.5$ because $x_{1}=x_{2}$.

Now, had the infringer (firm 2) not infringed, the patent owner (firm 1) would have been a legally sanctioned monopolist, and its profit-maximizing output $\left(x^{M}\right)$, price $\left(p^{M}\right)$, and the resulting but-forinfringement monopoly profits $\left(\pi^{M}\right)$ would have been written as follows:

$$
\begin{aligned}
x^{M} & =\frac{a-c}{2 h} \\
p^{M} & =\frac{a+c}{2} \\
\pi^{M} & =\frac{(a-c)^{2}}{4 h}
\end{aligned}
$$

Therefore, the ratio of the patent owner's profits as a monopolist in the absence of infringement profits $\left(\pi^{M}\right)$ to its actual profits with infringement $\left(\pi^{A}\right)$ can be expressed as follows:

$$
\frac{\pi^{M}}{\pi^{A}}=\frac{\text { prof its withoutinf ringement }}{\text { profitswithinf ringement }}
$$

Thus, we can write

$$
\text { Damage Percentage }=\frac{\pi^{M}}{\pi^{A}}=\frac{(1+s)^{2}}{4 s^{2}}-1.0
$$

Details of the derivation of (10) are shown in the Mathematical Appendix. In the symmetrical case in which neither firm had a cost advantage, then the patent owner would have a market share $s=.5$. In that case, the ratio of $\pi^{M}$ to $\pi^{A}$ equals $9 / 4$ or 2.25. Since the ratio of monopoly profits to actual profits is 2.25 , then actual patent owner profits need to be multiplied times $1.25(=2.25-1.0)$ in order to get the profits (or lost profits damages) the owner should have had. ${ }^{15}$

\section{Details from classic court cases in our database}

This section reviews seven U.S. federal court cases on patent infringement in 1970, 1983, 1989 and in the 1990s that constitute our actual versus predicted lost profits percentages. These are the cases from which the data was taken that is shown in Figure 1.

In Broadview Chemical v. Loctite Corporation (1970), plaintiff Loctite was awarded lost profits damages on Broadview's infringing sales of an anaerobic sealant. ${ }^{16}$ Loctite also received a $20 \%$ royalty rate on

\footnotetext{
15 In the symmetrical cases in which the two firms have equal; marginal costs, $\mathrm{k}=1$. Otherwise, firm 2 marginal costs differ from firm 1's since $\mathrm{c}_{2}=\mathrm{kc}_{1}$. Firm 2's marginal costs are higher than firm 1 if $\mathrm{k}>1$. 16 Broadview Chemical Corp. v. Loctite Corp., 311 F. Supp. 447, 454 (D. Conn. 1970).
} 
Broadview's foreign sales and its attorney's fees. The court determined that Loctite would have earned an incremental profit margin of $60 \%$ on the infringing sales by Broadview from 1967 through 1969 . The court stated that its purpose was "not to punish the defendant for his offense but to compensate the plaintiff for his injuries."

Industries lost profits on $40 \%$ of defendant Mor-F1o's sales of infringing water heaters. ${ }^{17}$ The court awarded a 3\% royalty rate on the remaining $60 \%$ of infringing sales, all of which occurred between 1984 and 1988. Patent owner State Industries had $\$ 155$ million in sales while infringer Mor-Flo had sales of $\$ 84$ million. As in Broadview, the court awarded patent owner State Industries its incremental profit margin on lost sales.

In Modine Manufacturing $v$. Allen Group (1989), plaintiff and patent owner Modine was awarded $\$ 9.8$ million in lost profits damages (\$2.2 million on lost sales and $\$ 7.6$ million on price erosion) on $50 \%$ or infringer Allen's sales. ${ }^{18}$ The innovations at issue related to welding and solder backfilling embodied in car and truck radiators. The court determined that the product prices that patent owner Modine received were depressed by $5 \%$ because of the infringing sales. Modine then agreed to accept the $\$ 9.8$ million in lost profits and \$4.1 million in royalty damages for a total of nearly \$14 million rather than staring a new trial.

In Micro Motion v. Exac Corporation (1991), the court awarded patent owner Micro \$14.6 million from price erosion and $\$ 4.2$ million from lost sales against infringer Exac. ${ }^{19}$ Micro also received a $15 \%$ royalty on infringing sales by Exac that Micro itself would not have made, but which used Micro's patent and \$5.4 million in prejudgment interest. Micro's patent is embodied in flowmeters which measure the mass flow of liquids. No attorney's fees were awarded to Micro because Exac's infringement was not found to be willful.

In Minco n. Combustion Engineering (1995), the court awarded patent owner Minco $\$ 3.5$ million in lost profits damages and $\$ 7.4$ million in reasonable royalties.20 Because of willful infringement, both awards were doubled, giving Minco \$7.0 million in lost profits damages; doubled royalties plus interest and attorney fees. The patents are contained in rotary furnaces used to fuse minerals.

In Pfizer v. International Rectifier Corporation (1983), pharmaceutical patent holder Pfizer obtained lost profits damages of $\$ 55$ million from International for infringement of Pfizer patents on its second-generation tetracycline product.21 The damages were composed of \$38 million in lost sales and \$17 million in price erosion because of International's infringement.

In W.R. Grace v. Intercat and Conoco (1999), the court found that patent owner Grace was entitled to recover for lost sales of $\$ 4.9$ million and for price erosion of $\$ 3.9$ million for a total lost profits damage of $\$ 8.8$ million. ${ }^{22}$ Because the Court found that the infringement was willful, Grace's lost profits damage was doubled to $\$ 17.6$ million. Grace's patents were on a composition to reduce sulfur dioxide emissions from hydrocarbon conversion.

17 State Indus., Inc. v. Mor-Flo Indus., Inc., 883 F.2d 1573, 1578 (Fed. Cir. 1989).

18 Modine Mfg, Co. v. Allen Group, Inc., 1989 U.S. Dist. LEXIS 16413, (N.D. Cal. 1989).

${ }_{19}$ Micro Motion, Inc. v. Exac Corp., 761 F. Supp. 1420, 1436 (N.D. Cal. 1991).

${ }^{20}$ Minco, Inc. v. Combustion Eng'g, 903 F. Supp. 1204, 1995 U.S. Dist. LEXIS 19658, (E.D. Tenn. 1995).

21 Pfizer, Inc. v. Int'1 Rectifier Corp., 685 F.2d 357, 359 (9th Cir. 1982).

22 WR Grace \& Co.-Conn. v. Intercat, Inc., 60 F. Supp. 2 d 316 (D. Del. 1999). 


\begin{tabular}{|c|c|c|c|c|c|c|c|c|}
\hline A & B & C & $\mathbf{D}$ & $\mathbf{E}$ & $\mathbf{F}$ & G & $\mathbf{H}$ & $\mathbf{I}$ \\
\hline Case & $\begin{array}{c}\text { Year of } \\
\text { decision }\end{array}$ & $\begin{array}{c}\text { Patent } \\
\text { Owner } \\
\text { Share, } \\
\text { s }\end{array}$ & $\begin{array}{c}\text { Infringer } \\
\text { Share }\end{array}$ & 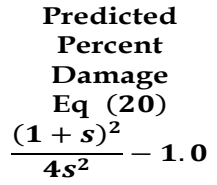 & $\begin{array}{c}\text { Initial } \\
\text { Decision } \\
\text { Percent in } \\
\text { the Case }\end{array}$ & $\begin{array}{c}\% \% \\
\text { Predicted } \\
\text { - Actual }\end{array}$ & $\begin{array}{c}\text { Final } \\
\text { Decision } \\
\text { Percent in } \\
\text { the case }\end{array}$ & $\begin{array}{c}\% \% \\
\text { Predicted } \\
\text { - Actual }\end{array}$ \\
\hline Minco & 1996 & 0.276 & 0.724 & 4.345 & 2.126 & 104 & 4.252 & 2 \\
\hline WR Grace & 1999 & 0.642 & 0.358 & 0.636 & 0.553 & 15 & 1.106 & -42 \\
\hline State & 1989 & 0.649 & 0.351 & 0.614 & 0.540 & 14 & 0.540 & 14 \\
\hline Modine & 1990 & 0.695 & 0.305 & 0.488 & 1.479 & -67 & 0.493 & -1 \\
\hline Pfizer & 1983 & 0.859 & 0.141 & 0.172 & 0.222 & -23 & 0.222 & -23 \\
\hline Micro & 1991 & 0.919 & 0.081 & 0.090 & 0.310 & -71 & 0.310 & -71 \\
\hline $\begin{array}{l}\text { Broadvie } \\
\mathbf{w}\end{array}$ & 1970 & 0.970 & 0.030 & 0.031 & 0.032 & -3 & 0.032 & -3 \\
\hline & & \multicolumn{3}{|c|}{ Mean Difference } & & $-4 \%$ & & $-18 \%$ \\
\hline & & & \multicolumn{2}{|c|}{ Mean Absolute Difference } & & $43 \%$ & & $22 \%$ \\
\hline
\end{tabular}

The Lost Profits Damage Percent: Initial Court Rulings vs Final Rulings After Appeal

How well does our formula predict the infringement lost profits damage awards in these seven cases? The results are tabulated in Table 2. To calculate the predicted damage ratio in column E, we use the Damage Multiple (Equation 10) applied to this data. He table does not include reasonable royalties (which are not about lost profits), legal fees or willful infringement

\section{Conclusions, Limitations and Direction for Future Research}

There are three major conclusions. One, we derive the simplest duopoly/monopoly damage equation we have seen that captures all major economic drivers of lost profits damages in a single percentage number. Second, that damage percentage multiplied times the patent owner's actual profits (with infringement ongoing) equals what the infringer should pay the patent owner in lost profits damages. Third, we found that our equation's damage predictions had a correlation of .71 with the actual Federal court damage outcomes in a small pilot study.

One limitation of the paper is that it applies only to product enhancement patents and not to cost saving patents. Second, we assume that the patent sufficiently differentiates the two firm's products that they have no close substitutes and operate in a separate duopoly submarket. Third, we assume no noninfringing substitutes to the patented products. Limitations two and three can be handled in actual court cases from testimony by economic experts. A fourth limitation is that our damage formula does no account for willful infringement, which is behavioral and outside the scope of this study.

Future research could address the limitations above and incorporate into the model other economic drivers of patent lost profits damages.

\section{References: Academic and Court Cases}

Anton, J. J. and Yao, D. A. (2007) 'Finding “lost” profits: An equilibrium analysis of patent infringement damages', Journal of Law, Economics, and Organization, 23(1), pp. 186-207. doi: 10.1093/jleo/ewm008.

Bohrer, D., Lynde, M. and Morris, E. M. N. (2009) 'The Shifting Sands of Price Erosion: Price Erosion Damages Shift by Tens of Millions of Dolalrs Depending Upon the Admissibility of Pre-Notice Eroded Prices', Santa Clara Computer and High - Technology Law Journal, 25(4), pp. 723-763.

Broadview Chemical Corporation v. Loctite Corporation, 311 F. Supp. 447, 1970 U.S. Dist. Lexis 13387, 164 U.S.P.Q. (BNA) 419 (United States District Court for the District of Connecticut January 2, 1970 
Choi, J. P. (2009) 'Alternative damage rules and probabilistic intellectual property rights: Unjust enrichment, lost profits, and reasonable royalty remedies', Information Economics and Policy. Elsevier B.V., 21(2), pp. 145-157. doi: 10.1016/j.infoecopol.2008.11.001.

Policy, 21(2), 145-157. https:/ / doi.org/10.1016/j.infoecopol.2008.11.001

Crystal Semiconductor Corporation, Plaintiff-Appellant, v. Tritech Microelectronics International, Inc. and Tritech Microelectronics International Pte Ltd., Defendants-Cross Appellants, and Opti, Inc., Defendant., 246 F.3D 1336, 2001 U.S. App. Lexis 3553, 57 U.S.P.Q.2D (BNA) 1953 (United States Court of Appeals for the Federal Circuit March 7, 2001, Decided).

Epstein, R. J. (2003) 'The Market Share Rule with Price Erosion: Patent Infringement Lost Profits Damages After Crystal', AIPLA Quarterly Journal, 31(1), pp. 1-46. doi: 10.3366/ajicl.2011.0005.

Gaff, B. M. (2015) Patent Infringement Damages, Computer. doi: 10.1109/MC.2015.330.

Gould, D. M. and Gruben, W. C. (1996) 'The role of intellectual property rights in economic growth', Journal of Development Economics, 48(2), pp. 323-350. doi: 10.1016/0304-3878(95)00039-9.

Henry, M. D. and Turner, J. L. (2010) 'Patent Damages and Spatial Competition', The Journal of Industrial Economics, 58(2), pp. 279-305. Available at: http://www.jstor.org/stable/40662184.

Janicke, P. M. and Ren, L. (2006) 'Who Wins Patent Infringement Cases?', AIPLA Quarterly Journal, $34(1)$, pp. 1-43. doi: 10.3366/ajicl.2011.0005.

Lex Machina (2014) Lex Machina Patent Litigation Damages Reference Sheet. doi: https://lexmachina.com/wpcontent/uploads/2014/12/Damages-Reference-Sheet.pdf.

Lex Machina (2018) Lex Machina's Fifth Annual Patent Litigation Year in Review Report Quantifies the Impact of the Landmark TC Heartland v. Kraft Supreme Court Case. doi: https://lexmachina.com/media/press/lexmachinas-fifth-annual-patent-litigation-year-review-report-quantifies-impact-landmark-tc-heartland-v-kraftsupreme-court-case/.

Micro Motion, Incorporated, Plaintiff, v. Exac Corporation, Defendant, 761 F. Supp. 1420, 1991 U.S. Dist. Lexis 4843,91 Daily Journal DAR 4595, 19 U.S.P.Q.2D (BNA) 1001 (United States District Court for the Northern District of California February 27, 1991, Filed).

Minco, Inc. v. Combustion Engineering, Inc., 903 F. Supp. 1204, 1995 U.S. Dist. Lexis 19653 (United States District Court for the Eastern District of Tennessee June 22, 1995, Filed).

Modine Manufacturing Co., Plaintiff, v. The Allen Group, Inc. D/B/A/ The G \& O Manufacturing Co., Defendant, 1989 U.S. Dist. Lexis 16413, 14 U.S.P.Q.2D (BNA) 1210 (United States District Court for the Northern District of California November 30, 1989, filed; December 4, 1989, Entered).

Nicholson, W. and Snyder, C. (2008) Microeconomic Theory: Basic Principles and Extensions. 10th edn. Mason, Ohio: Thomson/South-Western.

Nieberding, J. F. (2003) 'Lost Profits and Price Erosion in Patent Infringement Cases: Implications of " Crystal Semiconductor "', Journal of Forensic Economics, 16(1), pp. 37-49. Available at:

http://www.jstor.org/stable/42755931.

Panduit Corp., Plaintiff-Appellant, v. Stahlin Bros. Fibre Works, Inc., Defendant-Appellee, 575 F.2d 1152,1978 U.S. App. Lexis 11500, 197 U.S.P.Q. (BNA) 726 (United States Court of Appeals for the Sixth Circuit April 25, 1978, Decided and Filed).

Pfizer, Inc., Plaintiff-Appellee, v. International Rectifier Corporation, Rachelle Laboratories Italia, S.P.A., Rachelle Laboratories, Inc., Rachelle Pharmaceuticals International, S.A., Defendants-Appellants, 685 F.2d 357, 1982 U.S. App. Lexis 16320, 217 U.S.P.Q. (BNA) 39 (United States Court of Appeals for the Ninth Circuit August 26, 1982).

Pridham, D. (2017) 'The Patent Litigation Lie', Forbes. doi:

https://www.forbes.com/sites/davidpridham/2017/04/13/the-patent-litigation-lie/\#3678a157ea99.

Schankerman, M. and Scotchmer, S. (2001) 'Damages and Injunctions in Protecting Intellectual Property', The RAND Journal of Economics, 32(1), pp. 199-220. Available at: http://www.jstor.org/stable/2696404 Accessed:

Schankerman, M. and Scotchmer, S. (2005) 'Still Looking for Lost Profits: The Case of Horizontal Competition', UC Berkeley: Department of Economics, UCB. doi: 10.2139/ssrn.896165.

Tirole, J. (1988) The Theory of Industrial Organization. Cambridge, Massachusetts: The MIT Press. 
W.R. Grace \& Co.-Conn., Plaintiff, v. Intercat, Inc. And Conoco, Inc., Defendants., 60 F. Supp. 2d 316, 1999 U.S. Dist. Lexis 12449, 52 U.S.P.Q.2D (BNA) 1331 (United States District Court for the District of Delaware August 9, 1999, Decided).

Werden, G. J., Froeb, L. and Langenfeld, J. (2000) 'Lost Profits from Patent Infringement: The Simulation Approach', International Journal of the Economics of Business, 7(2), pp. 213-227. doi: 10.1080/13571510050084541.

\section{Acknowledgements}

The authors are indebted to Francisco Alberto Castellanos Sosa for research assistance and especially to two people who helped write this paper: Keiko Hikino, the Director of Intellectual Property Research, Magee and Magee Consulting www.MageeandMagee.com and Dr. Jack Lu, Chief Economist and Partner of Intellectual Property Market Advisory Partners LLC $\underline{w w w}$.IPMAP.com and Senior Consultant to Magee and Magee Consulting. They also are indebted to Prof. Steven Tomlinson and William Hornung for ideas in prior drafts.

\section{Mathematical Appendix}

In the two-firm market with the infringer present, profit-maximization requires that

$$
\begin{aligned}
x_{1} & =\frac{a+(k-2) c}{3 h} \\
x_{2} & =\frac{a+(1-2 k) c}{3 h} \\
p^{A} & =\frac{a+(1+k) c}{3} \\
\pi^{A} & =\frac{[a+(k-2) c]^{3}}{9 h}
\end{aligned}
$$

Where:

$$
\begin{aligned}
& x_{1} \text { : patent owner's actual output with infringement } \\
& x_{2} \text { : infringer's actual output with infringement } \\
& p^{A} \text { : actual equilibrium price with infringement } \\
& \pi^{A} \text { : patent owner's actual profits with infringement }
\end{aligned}
$$

Using equations (11) and (12), we obtain the following equation, which shows the underlying economic determinants of firm 1's actual market share with infringement:

$$
s \equiv \frac{x_{1}}{x_{1}+x_{m}}=\frac{a+(k-2) c}{2 a-(k+1) c}
$$

Where: $\mathrm{s}=$ patent owner's actual market share with infringement

The term $a$ is the vertical intercept of the demand curve; $c$ equals the dollar value of the patent holding firm 1's marginal cost per unit; and $k$ reflects the multiple of firm 2's marginal costs over firm 1 's marginal costs $(k>1$ means that firm 2's costs are greater than firm 1 's and $k<1$ means the opposite). This formula shows that when neither firm has a cost advantage, firm 1's market share $\mathrm{s}=$ .5 (when $k$ equals 1.0). Of course, the patent owner firm 1's market share $s$ increases with $k$ (the multiple of firm 2's costs over firm 1 's costs). ${ }^{23}$

Now, had the infringer (firm 2) not infringed, the patent owner (firm 1) would have been a legally sanctioned monopolist in this market, and its profit-maximizing output $\left(x^{M}\right)$, price $\left(p^{M}\right)$, and the resulting but-for infringement monopoly profits $\left(\pi^{M}\right)$ would have been

${ }^{23}$ Notice that $\frac{\partial_{a}}{\partial_{k}}=\frac{3(a-c) e}{[(k+1) e-2 a]^{2}}>0$.

www.ijbed.org A Journal of the Academy of Business and Retail Management (ABRM) 


$$
\begin{aligned}
x^{M} & =\frac{a-c}{2 h} \\
p^{M} & =\frac{a+c}{2} \\
\pi^{M} & =\frac{(a-c)^{2}}{4 h}
\end{aligned}
$$

Therefore, the ratio of the patent owner's but-for infringement profits $\left(\pi^{M}\right)$ to its actual profits under infringement $\left(\pi^{A}\right)$ can be expressed as follows:

$$
\frac{\pi^{M}}{\pi^{A}}=\frac{9(a-c)^{2}}{4[a+(k-2) c]^{2}}
$$

In the symmetrical case in which neither firm had a cost advantage (i.e., $k=1$ ), the ratio of $\pi^{M}$ to $\pi^{A}$ equals $9 / 4$ or 2.25 . Since the ratio of monopoly profits to actual profits is 2.25 , then actual patent owner profits should be increased by $1.25(=2.25-1.0)$. Thus, the monopoly patent owner should receive patent infringement damages equal to $5 / 4$ or 1.25 times the patent owner's actual profits during the period of infringement.

Combining all these equations, we obtain the simple formula that allows us to calculate the patent owner's lost profits with infringement as follows:

$$
\begin{aligned}
x_{1} & =\frac{(a-c) s}{b(1+s)} \\
x_{2} & =\frac{(s-1)(c-a)}{b(1+s)} \\
p^{A} & =\frac{c+a s}{1+a} \\
\pi^{A} & =\frac{[(a-c) s]^{2}}{b(1+s)^{2}}
\end{aligned}
$$

Combining equations (18) and (23), thus, we obtain the simple formula that allows us to calculate the patent owner's lost profits under infringement as follows:

$$
\begin{aligned}
\frac{\pi^{M}}{\pi^{A}} & =\frac{\left(2 s_{1}+s_{2}\right)^{2}}{4 s_{1}^{2}} \\
& =\frac{(1+s)^{2}}{4 s^{2}}
\end{aligned}
$$

Where:

$$
\begin{aligned}
& s_{1} \text { : patent owner's actual market share with infringement }(=s) \\
& s_{2} \text { : infringer's actual market share with infringement }(=1-s)
\end{aligned}
$$

Equation (24) tells us the essential term needed to estimate the patent owner's lost profit percent due to patent infringement based only on the patent owner's market share during the period of infringement. We assume there are only two sellers of the product so that these market shares sum to 1.0. Since we have used marginal cost in all our formulas, the proper accounting measure of actual profits is "gross profits." Therefore, the formula for lost-profits infringement damages for patent owner recovery from the infringing firm is:

Patent Infringement Damages = Damage Percentage $\mathrm{X}$

Patent Owner's Gross Profits in the Infringement Period

Table 1 in the text shows illustrative patent infringement lost profits damages using our model. The approximations in Table 1 equal equation (24) minus 1.0 shown in equation (26):

$$
\text { Damage Percentage }=\frac{(1+s)^{2}}{4 \pi^{2}}-1.0
$$

